\title{
PENGARUH LEVARAGE, UKURAN PERUSAHAAN DAN PROFITABILITAS TERHADAP PENGUNGKAPAN INFORMASI LAPORAN KEUANGAN PERUSAHAAN MANUFAKTUR YANG TERDAFTAR DI BEI 2008-2012
}

\author{
Monang Situmorang \\ Dosen Tetap Fakultas Ekonomi Universitas Pakuan \\ Lecturer of Economic Faculty at Pakuan University \\ Neng Lia Yuliawati \\ Mahasiswa Fakultas Ekonomi Universitas Pakuan \\ Student of Economic Faculty at Pakuan University
}

\begin{abstract}
ABSTRAK
Jenis penelitian yang digunakan dalam skripsi ini adalah verrifikatif, dengan metode penelitian yang digunakan adalah explanatory survey, dan teknik penelitian yang digunakan oleh penulis adalah statisttik deskriptif dan statistic inferensial. Populasi dalam penelitian ini adalah perusahaan manufaktur yang terdaftar di Burs Efek Indonesia Periode 2008-2012. Pengambilan sampel dilakukan berdasarkan metode purposive sampling, sehingga diperoleh sampel sebanyak enam perusahaan. Metode analisis menggunakan Regresi Linear Berganda, dengan pengujian hipotesis uji statistic t dan ujji statistic F serta menggunakan alat bantu SPSS. Hasil penelitian menunjukan bahwa tingkat Leverage dan profitabilitas perusahaan sampel mengalami fluktuasi kearah yang kurang baik sedangkan ukuran perusahaan setiap tahunnya mengalami peningkatan. Berdasarkan penngujian statistic secara simultan leverage, ukuran perusahaan dan profitabilitas berpengaruh signifikan terhadap pengungkapan informasi laporan keuangan. Sementara secara parsial hanya ukuran perusahaan yang berpengaruh secara signifikan terhadap pengungkapan informasi laporan keuangan, seedangkan leverage dan profitabilitas tidak berpengaruh signifikan terhadap pengungkapan informasi laporan keuangan.
\end{abstract}

Kata Kunci: Pengungkapan Informasi Laporan Keuangan, leverage, ukuran perusahaan dan profitabilitas.

\begin{abstract}
The type of research in this thesis is the verification, the method used in this research is an explanatory survey, and research techniques used by the author is statistic descriptive and inferential statistics. Population in this research are manufacturing companies listed in Indonesia Stock Burs period 20082012. Sampling was done by purposive sampling method, in order to obtain a sample of six companies. Methods of analysis using multiple linear regression, with statistical test of hypothesis testing and testing statistic $F$ and using SPSS. The results showed that the level of leverage and profitability of the sample companies fluctuated towards less result, while the size of the company every year has increased. Based on statistical tested as leverage simultaneously, The Company size and profitability significantly influence to the disclosure of financial statement information. While partially only the size of the company that significantly affect the disclosure of financial statements, while leverage and profitability have no significant effect on the disclosure of financial statement information.
\end{abstract}

Keywords: Disclosure of Financial Statements, leverage, firm size and profitability.

\section{PENDAHULUAN}

Laporan keuangan merupakan sumber berbagai macam informasi bagi investor sebagai salah satu dasar pertimbangan dalam pertimbangan dala pengambilan keputusan investasi di pasar modal, juga sebagai sarana pertanggungjawaban manajemen atas sumber daya yang dipercayakan kepadanya. Kualitas informasi keuangan tercermin pada sejauhmana luas pengungkapan laporan yang diterbitkan perusahaan. Pengungkapan (disclosure) dibedakan menjadi dua yaitu mandatory disclosure (pengungkapan wajib) dan voluntary disclosure (pengungkapan sukarela). 
Dari jenis-jenis industry tersebut, industry manufaktur merupakan perusahaan yang paling banyak memberikan pengungkapan dalam laporan keuangan tahunnya. Adapun perusahaan manufaktur yang diambil sebagai bahan penelitian ini berjumlah 6 perusahaan. Jenis usaha dalam sampel perusahaan adalah perusahaan automotive abd compenents sebanyak 2 perusahaan, yaitu : Astra Otoparts Tbk dan Gajah Tunggal Tbk. Food and beverages sebanyak 2 perusahaan, yaitu : Delta Djakarta Tbk dan Indofood Sukses Makmur Tbk. Kemudian Cement sebanyak 2 perusahaan, yaitu : Indocement Tunggal Prakrsa Tbk, dan Semen Gresik (Persero) Tbk. Perusahaan-perusahaan di atas harus lebihh banyak melakukan pengungkapan informasi laporan keuangannya karena dapat meningkatkan kepercayaan investor, kreditur, dan stockholder serta berkesempatan mengembangkan perusahaannya.

Setelah mengetahui tingkat leverage dengan menggunakan debt to equty ratio, besar ukuran perrusahaan dengan menggunkan logarithm of total asset, daan tingkat profitabilitas denggan menggunakan return on asset dari ke enam perusahaan manufaktur diatas, maka akan dapat diketahui dan dibbandingkan seberapa tinggi atau rendahnya kenaikan atau penurunan dari jumlah leverage, ukuran perusahaan serta profitabilitas dari enam perusahaan tersebut.

Mengingat informasi laporan keuangan merupakan hal yang penting bagi suatu perusahaan yang berguna untuk pihak-pihak yang berkepentingan, maka penulis tertarik untuk melakukan penelitian dengan judul : "Pengaruh leverage, ukuran perusahaan dan profittabilitas terhadap pengungkapan informasi laporan keuangan perusahaan manufaktur yang terdaftar di BEI tahun 20082012".

Oleh karena itu tujuan dari penelitian ini adalah: 1) Untuk mengetahui leverage, ukuran perusahaan, dan profitabilitas pada perusahaan manufaktru yang terdaftar di BEI 2008-20012; 2) Untuk mengetahui pengungkapan informasi laporan keuangan pada perusahaan manufaktur yang terdaftar di BEI tahun 2008-2012; dan 3) Untuk mengetahui pengaruh leverage, ukuran perusahaan dan profitabilitas terhadap pengungkapan informasi laporan keuangan padaa perusahaan manufaktur yang terdaftar di BEI 2008-2012.

\section{METODE PENELITIAN}

Jenis penelitian yang digunakan dalam penelitian ini adalah verifikatif. Dalam hal ini penelitian verifikatif dilakukan penulis ddengan tujuan untuk mengetahui pengaruh leverage, ukuran perusahaan dan profitabilitas terhadap pengungkapan informasi laporan keuangan pada perusahaaan manufaktur yang terdaftar di BEI. Metode penelitian yang digunakan adalah explanatory survey, teknik penelitian yang digunakan adalah statistic deskriptif dan statistic inferensial. Unit analisis yang digunakan dalam penelitian ini berupa Organization, dalam hal ini unit analisisnya adalah data keuangan pada perusahaan manufaktur yang terdaftar di Bursa Efek Indonesi pada tahun 20082012. Untuk memudahkan proses analisa, maka penulis mengklasifikasi variabel penelitian, yaitu variabel independen (leverage, ukuran perrusahaan dan profitabilitas) dan variabel dependen (pengungkapan informasi laporan keuangan).

Metode penarikan sampel dilakukan berdasarkan metode cluster sampling, sedangkan pengambilan sampel dilakukan berdasarkan metode 
purposive sampling. Prosedur pengumpulan data yang dilakukan penulis dilakukan dengan dua cara, yaitu penelusuran data sekunder secara manual dan penelusuran dengan computer. Metode analisis yang digunakan dalam penelitin ini adalah analisis kuantitatif berupa pengujian hipotesis dengan menggunakan uji statistic model regresi linier berganda dan pengujian menggunakan software SPSS berupa Analisis Statistik Deskriptif, uji asumsi klasik (uji normalitas, uji multikolonieritas, uji autokorelasi, uji heterokedastisitas. Pengujian hipotesis berupa Analisis Regresi Berganda, Analisis Koefisien Determinasi, uji F, uji signifikansi parameter individual (Uji Statisti t).

\section{HASIL DAN PEMBAHASAN}

Data Leverage pada perusahaan Manufaktur yang terdaftar di BEI. Hasil dari olah data dapat disimpulkan bahwa untuk debt to equity bahwa rata-rata sampel perusahaan dari tahun 2008-2012 berfluktuasi, tahun 2008-2010 mengalami penurunan dan tahun 20112012 mengalami peningkatan yang artinya bahwa perusahaan umumnya pendanaan utang dalam bauran modal mereka dibandingkan dengan saham atau ekuitas.

Data Ukuran perusahaan pada perusahaan Manufaktur yang terdaftar di BEI. Dari data logarithm natural of total asset tersebut di atas dapat diketahui bahwa rata-rata sampel perusahaan dari tahu 2008-2012 mengalami kenaikan yang artinya perrusahaan tersebut dalam keadaan baik karena jumlah asset yang dimiliki perusahaan semakin bertambah berarti perusahaan mengalmi perkembangan

Data profitabilitas pada perusahaan Manufaktur yang terdaftar di BEI. Dari data return on asset tersebut dapat diketahui bahwa rata-rata sampel perusahaan dari tahun2008-2012

berfluktuasi, tahun 2008-2009 meengalami peningkatan dan tahun 2009-2012 mengalami penurunan tetapi masih pada taraf wajar. Peningkatan rasio ini mencerminkan kinerja perusahaan dalam keadaan bail, semakin tinggi rasio ini semakin besar kemungkinan perrusahaan mengungkapkan informasi laporan keuangan yang lebih lengkap.

Data pengungkapan informasi laporan keuangan pada perusahaan Manufaktur yang terdaftar di BEI. Dari data disclosure index tersebut $\mathrm{di}$ atas dapat diketahui bahwa rata-rata sampel perusahaan dari tahun 2008-2012 mengalami kenaikan yang kecil artinya perusahaan tersebut setiap tahunnya mengungkapkan lebih banyak infromasi laporan keuangannya dibandingkan dengan tahun-tahun seebelumnya.

Pengujian pengaruh leverage terhadap pengungkapan informasi laporan keuangan menggunakan regresi berganda menunjukkan hasil yang tidak signifikan. Hal ini dapat dilihhat pada nilai signifikansinya sebesar 0.0006 yang lebih kecil dari $\alpha=0.05$, sedangkan $\mathrm{t}$ hitung $<\mathrm{t}$ table $(-2,923<2,04841)$. Berdasarkan hasil pengujian regresi berganda secara individual dapat disimpulkan bahwa hipotesis H1 yang menyatakan bahwa leverage berpengaruh terhadap pengungkapan informasi laporan keuangan ditolak.

Pengujian pengaruh ukuran perusahaan pengungkapan informasi laporan keuangan menggunakan regresi berganda menunjukkan hasil yang signifikan. Hal ini dapat dilihhat pada nilai signifikansinya sebesar 0.000 yang lebih kecil dari $\alpha=0.05$. Berdasarkan hasil pengujian regresi berganda secara individual dapat disimpulkan bahwa hipotesis $\mathrm{H} 2$ yang menyatakan bahwa Ukuran Perusahaan berpengaruh 
terhadap pengungkapan informasi laporan keuangan dapat diterima.

Pengujian pengaruh profitabilitas pengungkapan informasi laporan keuangan menggunakan regresi berganda menunjukkan hasil yang tidak signifikan. Hal ini dapat dilihhat pada nilai signifikansinya sebesar 0.158 yang lebih kecil dari $\alpha=0.05$. Berdasarkan hasil pengujian regresi berganda secara individual dapat disimpulkan bahwa hipotesis H3 yang menyatakan bahwa Ukuran Perusahaan berpengaruh terhadap pengungkapan informasi laporan keuangan ditolak.

\subsection{Pembahasan Hasil Penelitian}

Penelitian ini menguji pengaruh leverage, ukuran perusahaan dan profitabilitas terhaddap pengungkapan informasi lapooran keuangan. Berdasarkan pada pengujian empiris yang telah dilakukan terhadap beberapa hipotesis dalam penelitian, hasilnya menunjukan bahwa tidak semua variable independen diatas berpengaruh signifikan terhadap variable dependen. Factor-faktor yang berpengaruh signifikan terhadap pengungkapan informasi laporan keuangan hanya ukuran perusahaan.

\section{SIMPULAN}

1. Perusahaan manufaktur padaa periode 2008-2012 memiliki tingkat leverage dan tingkat profitabilitas yang berfluktusi kea rah yang kurang baik tetapi ukuran perusahaan rata-rata perusahaan sampel mengalami kenaikan jumlah asset setiap tahunnya. Hal tersebut ditunjukkan berdasarkan data yang diperoleh dari perusahaan dimana untuk tingkat leverage dengan indicator debt to equity ratio bahwa rata-rata sampel perusahaan dari tahun 2008-2012 berfluktuasi, tahun 2008-2010 mengalami penurunan dan tahun 2011-2012 mengalami peningkatan yang artinya bahwa perusahaan umumnya menggunakan pendanaan utng dalam bauran modal mereka dibandingkan dengan saham atau ekuitas. Total asset yang merupakan proksi dari ukuran perusahaan setiap tahunnya mengalami peningkatan dengan kata lain set yang dimiliki perusahaan setiap tahunnya bertambah. Untuk tingkat profitabilitas dengan indicator return on asset daapat diketahui bahwa rata-rata sampel perusahaan dari tahun 2008-2012 berfluktuasi, tahun 2008-2009 mengalmi peningkatan dan tahun 2009-201 mengalami penurunan tetapi masih pada taraaf wajar. Penurunan rasio ini mencerinkan kinerja perusahaan dalam keadaan kurang baik.

2. Pengungkapan informasi laporan keuangan yang dilakukan masingmasing perusahaan berbeda-bedaa, bergantung risiko yang akan dihadapi perusahaan tersebut. Pengungkapan informasi laporan keuangan dengan indicator disclosure index dapat diketahui bahwa rata-rata sampel perusahaan daritahun 2008-2012 mengalami kenaikan yang kecil artinya perusahaan tersebut setiap tahunnya mengungkapkan lebih banyak informasi laporan keuangannya dibandingkan dengan tahun-tahun sebelumnya.

3. Hasil penelitian dengan pengujian statistic menunjukkan secara simultan (bersama-sama) leverage, ukuran perusahaan dan profitabilitas berpengaruh signifikan terhadap pengungkapan informasi laporan keuangan. Sementara secar parsial hanya 
ukuran perusahaan yang berpenngaruh signifikan terhadap pengungkapn informasi laporan keuangan, yang bearti bahwa semakin besar ukuran perusahaan, maka pengungkapan informasi laporan keuangan yang dilakukan oleh perusahaan akan semakin luas. Hal ini menunjukkan bahwa perusahaan yang mempunyai nilai logarithm natural of total asset besar yang merupakan indicator dari ukuran perusahaan, perusahaan tersebut memiliki kesadaran yang lebih tinggi terhadap praktek pengungkapan informasi laporan keuangan. Sedangkan leverage dan profitabilitas tidak berpengaruh signifikan terhadap pengungkapam informasi laporan keuangan.

\section{DAFTAR PUSTAKA}

Agus, Sartono. 2001. Manajemen Keuangan; aplikasi dan teori. Yogyakarta : BPFE-Yogyakarta.

Ahmad, Chuzairi. 2013. Faktor-faktor yang mempengaruhi pengungkapan CSR pad Perusahaan yang terdaftar di BEI. Jurnal Riset Akuntansi. Hal 7.

Almilia, Luciana Spica, dan Winny Herdiningtyas, 2007. "Analisa Rasio Camel terhadap Prediksi Kondisi Bermasalah pada Lembaga Perbankan Periode 20002002". Jurnal Akuntansi dan Keuangan. Volume 7 Nomor 2, STIE Perbanas, Surabaya, hal 12.

Ang, Robert. 1997. Buku Pintar Pasar Modal Indonesia. Jakarta: Media Staff Indonesia.

Belkaoui, Ahmed Riahi. 2007. Teori Akuntansi. Edisi Kelima. SAlemba Empat, Jakarta.

Eugene F. Brigham dan Joel F. Houston. 2008. Fundamental of Financial
Management. Jakarta: Salemba Empat.

Hendriksen, Eldon S. 2002. Teori Akuntansi, Edisi Keempat, Jilid I, Penerbit Erlangga, Jakarta.

Hadri, Kusuma. 2005. Faktor-faktor yang mempengaruhi Struktur Modal pada Perrusahaan Manufaktur Go Public yang Terdaftar di Bursa Efek Jakarta. Sinergi, Edisi Khusus On Finance: hlm. 1-15.

Kasmir. 2008. Analisis Laporan Keuangan, Raja Grafindo Persada, Jakarta.

Lukman, Syamsudin. 2007, Manajemen Keuangan Perusahaan. Jakarta: Raja Grafindo Persada.

PSAK 1 Revisi 2009 tentang Laporan Keuangan

Soemarsono, S.R, 2004. Akuntansi: Suatu Pengantar. Edisi Kelima, Buku 1, Penerbit Salemba Empat. Jakarta.

Sujoko. 2007. Pengaruh Struktur Kepemilikan Saham, Leverage, Faktor intern dan ektern terhadap Nilai Perusahaan. Jurnal Riset Akuntansi.

Susan, Irawati. 2006. Manajemen Keuangan. Bandung: Pustaka. 